\title{
Transformation of the Feminine Self in Yogamāya
}

\author{
Indira Acharya Mishra, $\mathrm{PhD}$
}

\begin{abstract}
This article aims to analyze the struggle of Yogamaya, the lead female character of the novel Yogamāyā, by Neelam Karki Niharika. The novel based on the real life story of a rebel, Yogamaya, chronicles the incidents of her life that triggered her to cast off her feminine self and rebel for the establishment of a just society based on equity. The article examines those factors that force Yogamaya to rebel against the existing society and the process of her rebellion drawing insights form Helen Cixous and other feminists who find patriarchal gender roles based on binary opposition as oppressive, and suggest that women should act beyond gender binary and subvert the patriarchal norms and values that restrict them in every walk of their lives. I use transliteration and free translation while citing from the novel in the analysis. The finding of the article suggests that a number of factors instigate Yogamaya cast of her feminine self and emerge as a rebel. It helps to understand how Yogamaya subverts patriarchy within its bound exposing the inherent biasness in it.
\end{abstract}

Keywords: Gender binary, feminism, feminist, feminine, subversion, patriarchy.

\section{Background}

Neelam Karki Niharika is a renowned figure in the field of Nepali literature. She has a distinguished position among the Nepali novelists because of her prize winning novels like Chīraharana, which is awarded with the prestigious Nepali literary award Padamashrī Sammāna (2072 BS), and Yogamāyā, which is awarded with the highest Nepali literary award, Madana Puraskāra (2074 BS). Besides these novels, she has published other novels as well. In most of her novels, she deals with the issues of women and strongly protests the marginalization, subjugation and ill-treatment of women in male dominated society. For example, in her novel Arkī Aāimmāì she exposes the predicament of an adolescent girl tied in a loveless marital bond. Likewise, in Chiraharana she rewrites the story of Draupadi of the Māhäbhārata from Draupadi's perspective. In her authorial note of Chïraharana, she mentions the factor that instigated her to write the novel from the female's perspective. She explains that a senior citizen's derogatory remarks to adolescent girls instigated her to write the novel. He opinionated that it was because of Draupadi's laughter at Duryodhana, the devastating war of the Māhābhärata occurred. This incident reminded her how women become scapegoats in 
patriarchy, and how the images of women as evil actress are created and circulated in the society. It also demonstrates the effect of myth making in people's outlook. There and then, she vowed that she would write a novel to destroy the myth of women as evil doer and would rewrite the story of the Mahäbhärata from women's perspectives (523). She suggests that such incidents illustrate how patriarchy fabricates the myth of women as evil doer to tame and control them.

Karki feels the urge to write about women advocating women's rights. She mentions that from the ancient time to present women are the tools in men's hands. Their lives and existence have been staked to meet the vested interests of men who they are subjected to. In her endeavor, Karki aligns with Helen Cixous, who believes that writing can transform social and political structures of the society. Advocating women writings, Cixous, in her seminal writing "The Laugh of the Medusa," pressingly invites women to write. She insists:

Woman must write herself: must write about women and bring women to writing, from which they have been driven away as violently as from their bodies - for the same reasons, by the same law, with the same fatal goal. Woman must put herself into the text — as into the world and into history— by her own movement. (874)

Cixous posits that women have been forced away from writing by men. Men have written history and commanded the laws of God, medicine, science, and writing/publishing and have used these public venues to define women as substandard and Other. In art and literature too, Cixous claims that men have shaped the identities of women to such an extent that women have come to believe themselves as they have been defined by men (878). Thus, she advises women to write about themselves from their own perspectives. Karki, too, has been writing about women from women's perspectives. She rescues her female protagonists from the negative stereotype femininity that define women as timid and submissive and uphold their character as dignified and courageous ones. In Yogamāy $\bar{a}$, she clears the mystery about Yogamaya through her research and brings Yogamaya's contributions in the limelight.

\section{Problem, Objectives and Methodology}

Yogamaya, the protagonist of the novel refuses to limit herself in the ascribed feminine gender roles. She trades into the role of a social reformer and revolutionist. From an ordinary illiterate rural girl, she transforms herself into a rebel feared by the rulers of the nation. In the process of her transformation, she has been ostracized, boycotted, shunned and exiled; yet she persists, and, finally, after she and her supporters get amnesty, she plunges into the fast flowing Arun River leading to a mass suicide. The way Yogamaya resists and rebels has motivated me to examine the transformation of her feminine self in the novel. In the process of analysis, the article answers the following research questions: 
50 JODEM: Journal of Language and Literature, vol. 10, no. 1, issue 12, 2019/2076BS

- What factors trigger her to be a rebel?

- How does she rebel and transform her feminine self?

The main objectives of the study are to examine the factors contributing Yogamaya's emergence as a rebel and to trace the process of her transformation from a helpless, despised rural girl to a rebel feared by the rulers of the nation. For this, it bases on Cixous' notion of subversion of patriarchy founded upon binary opposition.

Cixous believes that Western thought depends on binary oppositions such as Sun/Moon, Culture/Nature, Day/ Night, Intelligible/Sensitive or Activity/Passivity which ultimately relate to the dichotomy of Man/ Woman. Within each of these binary oppositions, Cixous points that woman is located as the negative instance. Each opposition operates as a hierarchy, replicating the underlying male/female paradigm, with its inescapable positive/negative associations. She explains that in this system of oppositions, whenever one element of the pair intends to make sense, one witnesses a "universal battlefield. Each time, a war is let loose. Death is always at work" ("Sorties" 149). According to her, these opposite terms are not on equal terms; but exist within a hierarchical relationship, in which one term must destroy the other. The battle ends in the death of the object, the female.

Moreover, Cixous claims that Western language is phallocentric; and in phallocentric language system woman is identified only as man's other: "Either woman is passive or she does not exist" ("Sorties"149). Phallocentrism deprives women of positive identity. Cixous correlates this lack of identity with death. She asserts: "Phallocentrism is the enemy. . . And it is the time to change. To invent the Other history" (" Sorties"154). Thus, in order to set women free from phallocentric oppression, Cixous suggests that women should act beyond the malecentric logic; they should defy the logic of binary oppositions. To assert their identity as active agent, Cixous invites women to writing. She suggests that women should write; they have to invent language of their own with subversive potential to wreck the law and the priorities erected by it ("Medusa" 887). Under 'Man's Law,' Masculine thrives in the death of the feminine. Thus, women should invent their own language that does not continue the language system based on binary oppositions. In the novel, Yogam $\bar{a} y \bar{a}$, Yogamaya resists the hierarchy of gender, caste and class. She demands that there should not be discrimination among people and fights for a just society based on equality. In this sense, Cixous' theory of resistance is compatible for the analysis of the novel.

\section{Review of Literature}

Yogamāya is a well acclaimed novel of Nepali literature. No sooner had it been published in 2018 than there appeared a host of critics with their reviews. Their reviews on the novel appeared on the national dailies and weekly of the nation. Kantipur Daily mentions that the 
novel is based on Karki's research on Yogamaya, a historical persona of Nepal. The review cites the comment made by Krishna Gautam who views that breaking the tradition of writing the history of the rulers, Karki, in the novel, chronicles people's history (14). The post also mentions comments made by Sabitri Kakshapati, and Barabara Nimri Aziz who view that documenting the contribution of a female persona, Karki has challenged the trend of men's history.

Critics Ramji Timalsina and Tika Atreya believe that Karki has done justice in the portrayal of Yogamaya, the female fighter of the early $20^{\text {th }}$ century Nepal. Timalsina appreciates Karki's art of narration and characterization. Based on the historical events, the novel is an artistic fusion of facts and human sentiments. As a historical novel, it is a par excellence; it portrays more than fifty characters taken from the history and none of them sounds exaggeration. The novel makes a lively address on the history of Yogamaya: restores Yogamaya's position as a social reformer, and dismisses the rumors about Yogamaya as the byproducts of pervading wrong ideology of the existing society (chha). Likewise, Atreya asserts that Yogamāya is a research based historical novel that makes a just verdict upon the female fighter, Yogamaya. She analyzes how Yogamaya audaciously fought for justice to women and other deprived people. Though the novel has feminist tilting, it raises social, economic and political issues as well. Atreya explains that Karki is successful in her attempts of documenting Yogamaya's contribution and removing the mystery that surrounded her personality (n. pag.). Timalsina and Atreya believe that Karki's novel does justice to Yogamaya by establishing her as a social reformer and freedom fighter.

Likewise, Bimal Bhaukaji claims that the novel is based on real life situations of historical people. He also appreciates Karki's art of writing a historical novel. For him, Yogamaya was not only a courageous woman but she was more rebellious than men. So, Bhaukaji wanders what were the factors that made an innocent girl, betrothed to an exploitative marriage, has emerged as a rebel, finally suicide? There must have been serious issues which forced her to abandon her first husband. This is a matter of search, Bhaukaji reasons (n.pag). Anjana Poudel, too, agrees that Karki has documented the historical incident that took place hundred years ago in the eastern Nepal. She also points to the facts that Karki has searched to remove the mystery about Yogamaya (n.pag). Both these critics agree that the novel documents the historical incident that took in the eastern hilly region of Nepal.

Barbara Nimri Aziz, the American anthropologist who has made a first sustained study of Yogamaya, explains that Yogamaya cannot be studied using the tools and methods of anthropology developed in the West. She is beyond the limit of anthropological analysis. She claims that Yogamaya was an extraordinary activist, in whom Nimri Aziz has found a female hero. She was a rebel who needs to be studied beyond the lens of anthropology; and Karki is 
successful in this venture (n.pag). Since Yogamaya is no more alive, an anthropologist cannot research on her using the anthropological tools. But, Karki, the novelist, has no methodological restriction, and this freedom has supported her to accomplish her research based study on Yogamaya.

There are other critics such as Amrit Bahadur Karki and Kiran Marahatta who also agree that the novel is a historical novel that deals with the real life situations of the historical persona, Yogamaya. All these critics appreciate Karki's art of novel. The way she documents the incidents that surround Yogamaya, they believe, removes the mystery or misconception about her. Thus, the novelist does justice to Yogamaya, according to these critics. These critics' opinions and ideas are important to understand the background of the novel and the character of its protagonist. However, they remain silent on why and how Yogamaya transforms herself as a rebel. Thus, the analysis below tries to address this gap.

\section{Transformation of Yogamaya's Feminine Self}

The novel Yogamāya, set in the eastern hilly region of Nepal, chronicles the real life events of a historical woman, Yogamaya, a social reformer and a rebel. It traces her journey from submission to leadership. Born in the middle class Brahmin family she has the ordinary life expectations like most of the girls from rural backgrounds have. She just wants to live happily in the company of her loved ones. She is hardworking, energetic and affectionate. Yet, she has a hard life. She suffers from undue suffering. She poignantly shares with her brother's wife, Ganga Devi, her confident:

ke bhanum dulahī. bãâchna khojẽ. khusī pani khojna ta khojẽ holā tara jahātah̄̄ duh khakai sāgra thyo. . . la lậko mānchhe uṭhera hị̃ana khojẽ. . . a āphū bācheko astitwa anubhaba garna khoje. sabka najarmā ma hã̃sna khojnu galtī. ma bãachna khojnu mahāgaltī. [What to say sister-in-law. I tried to live. I might have tried to be happy, but there was ocean of sorrows. . . I was a fallen person, but I tried to get up and walk. ... I tried to experience my lived existence. In the eyes of others, it was my fault to try to laugh. I did a grave mistake by attempting to live]. (101)

She explains that she has harmed none. However, she suffers throughout her life. In her attempt to live a dignified life, slowly and gradually, from the position of a subservient rural woman she transforms herself into a stoic rebel who fears no one and coveted by nothing on the earth. A number of factors contribute to her transformation from a despised submissive girl to a rebellious leader.

First and foremost her experiences as a woman spark the fire of rebellion in her. Gender based violence like child marriage, wife battering, burning of the widows, and collecting cowives are rampant in the society. She becomes a victim of gender based violence. At the very tender age, before puberty, she gets married and is sent away to her in-laws. Her in-laws 
mistreat and exploit her, deprive her of her basic needs like food and rest; and above all, they isolate her. She feels lonely and isolated and requests them to let her visit her parents. But they are non-responsive. She finds her situation worse than those of goats. So, secretly, she leaves her husband's house thinking that anything will be better than this dire situation. Unlike her expectation, her parents do not welcome her. Especially, her father denounces her for running away from her home and shaming his whole clan. He does not provide her shelter; rather he demands that she be taken back to her husband's house immediately. Her father, to keep his masculine ego intact (marda ko bolì) does not withdraws his decision.

At this stage, Yogamaya is too innocent to access the consequences of her audacious action. As soon as she steps out of the house, without asking for permission from her seniors, the tag of a bad woman is attached to her. She becomes a homeless, a castaway because her inlaws deny receiving her. In patriarchy, people do not have confidence and sympathy for a runaway wife for she is taken as having questionable character. Similarly, Yogamaya's in-laws question her character. She grimly reports: "mero charitramāthi po aulā uțāechhan. kurai teh̄̄ rātalāà lie re. kosãga kāhākāhã̃ basī tīna rāta bhandā rachhan. [They questioned my character. They raised the issue of the same night. They wondered who she spent three nights with]" (96). Her condition becomes more vulnerable once she leaves her home. Lois Tyson, a feminist, suggests that if a woman wants to survive, she needs to play the role of a good girl, a virgin who will be ideal wife and mother in future; a promiscuous with loose moral will be rejected from not only getting married but will also be socially excluded (89). They accuse her of having a loose moral character. She pleads, begs for mercy, but with no avail. She has to pay the price of breaking the tradition of taking permission for leaving the home. Her father blames her for staking his reputation by not bearing with her in-laws.

The response of her parents and their neighborhood to Yogamaya demonstrates how the patriarchal society limits women's independence by creating unrealistic standards for an "ideal woman," and stigmatizes women who fight against the system. She is treated as an outsider in her own parental home. Since she is a married one, other's property, her father fears that she has destroyed their reputation as being unable to adjust in her in-laws. So he keeps her under strict surveillance. Her father even accuses her of having an extramarital affair: "aba bachekhucheko ijjata pani sakiyo yo rẫdale gardā. [Now, the remaining reputation is also destroyed because of this slut]" (97). Her father blames her for shaming the family and acts violently towards her and her mother. The father, as a symbol of patriarch, uses abuses and scolds to control the women: Yogamaya and her mother. He blames Yogamaya's mother for not training Yogamaya in the proper feminine role.

The way Yogamaya's father mistreats her reveals that under patriarchy women, who fail to act feminine, get punished. Kate Millett, a feminist critic aptly observes that 
women who are not obedient towards those rules set for them will be intimidated. They may be subjected to "a variety of cruelties and barbarities" (quoted in Tong 52). In the name of tradition women's human rights also get violated. Yogamaya is even deprived of talking to men other than her relatives. Analyzing how women suffer in their own family, Susan Moller Okin mentions: "Many violations of women's basic human rights occur within families and are justified by reference to culture, religion or tradition" (33). It is quite unfeminine on Yogamaya's part to leave the house all alone. She fails to observe endurance and self-sacrifice and plays the role of a 'good wife.' Consequently, she suffers.

Though Yogamaya is a revolutionary by temperament, she endures her father's abuses and scolds. She lacks education, experience and exposure to the outside world. She keeps herself silent to the derogatory questions of the neighborhoods. She becomes the victims of Brahmin cultural notion of purity attached to women's body. She criticizes patriarchal biasness with regards to chastity and morality:

kati atyāchār. mardānāle mana lagdo garnahune. moja mastīko lāgi ātṭh-dasawațī jati joì rākhna hune. janānā bhane marnabhandā bahulāuna niko țānera ekabāta dwū̄ bho bhane bigriekī hune?

... usale je jāta lyāe pani māthiko māthi, swasnī mānchhe bhane. . jāta jharne? [How tyrannical! A man can do as par his wishes. He can collect eight or ten wives for pleasure and fun. But a woman gets spoiled if she marries a second husband in compulsion, thinking that madness is better than death.

Whoever a man marries he remains the upper caste, but a woman ... her caste lowers?] (109)

She exposes the unjust gender roles expectation of patriarchy from men and women. To maintain patriarchal monopoly on women's sexuality, they define it in terms of purity. Indeed, family's honor (ijjat) rests on women's behavior as Vrinda Nabar explains: ". . ijjat seems to be a female-linked commodity. Its preservation is incumbent upon the women's behavior alone, and it appears to be the prerogative to ensure that she does not jeopardize its delicate balance at any cost" (115). If a woman marries a second husband, incase her first marriage fails, she is taken as a spoiled one. But men's honour remains intact no matter how many wives he has. Likewise, in Brahmin community, a man's caste remains intact irrespective of his wife's caste. But a woman falls from her caste if she marries a lower caste man. Yogamaya criticizes the arbitrary rules of Brahmin culture which is highly exploitative to women. 
Desperate and rejected Yogamaya chooses exile. She elopes with Kandel, a non-Brahmin. She becomes a double custom breaker; so it would not be possible for her to stay in her parents' village among her relatives. Since she has been insulted as a fallen woman, in the given social milieu, her action supports her accusers. Thus, with her second husband she moves to Asam. She is honest, energetic and hardworking. So she has no problem to sustain herself. But misfortune keeps following her; her second husband dies. She becomes a widow. Again, she marries for the third time breaking the ban on widow marriage.

Though with the support of her husband, Yogamaya has been living a happy conjugal life with a daughter, she is in a dilemma. Because she is a transgressor; she has tasted the 'forbidden fruit.' For this, people humiliate and insult her: they back bite her as an adulteress, a fallen woman. She is unable to overcome the conservative notion attached to widow marrying. Besides, she listens to a priest who suggests that remarrying is a sin and one will not get redemption after death. Even if one has sexual relation with more than one person in ignorance, the priest explains that one should reform by discontinuing such relation after one knows its repercussion. One can reform oneself through repentance. Religion, as a tool to patriarchy, is used to manipulate women. Referring to the role of religion to maintain male domination on women, Simone de Beauvoir comments, "Legislators, priests, philosophers, writers, and scientists have striven to show that the subordinate position of woman is willed in heaven and advantageous on earth. The religions invented by men reflect this wish for domination" (Li). It can be inferred to Yogamaya's dilemma; she undergoes humiliation and debasement which result in negating her personal comfort. She abstains from sexual relation with her husband, who she loves to.

Yogamaya has been living the life of a recluse in her home when she comes in contact with some ascetics, who unlike the orthodox pilgrims, are liberal humanitarians and believe on doing something good for the others. She already has the spark of revolution inside her, but because of ignorance she is in dilemma, and now they rekindle it. She acknowledges some string of revolt in her. She decides to return to her own country and fight for justice. This marks a turning point in her life. Coincidently, her third husband, too, dies. But this time she is not devastated. She takes it as a bad luck. Now, she finds the role of a wife and mother unfulfilling for her. She listen to her inner voice and returns to her birthplace to liberate her fellow citizens who have been seared by gender and caste discriminations and lack of good governance.

In this sense, her own personal experiences as a victim of gender and caste based discriminations stimulate her to revolt against such malpractices. However, there are other factors as well. When she returns to Nepal, she finds caste system is deeply rooted in the society. Taking the support of religion, Brahmins are exploiting women and people of low castes. An elderly woman informs her that her father never forgave her for shaming the family. 
It is not that he did not love her, but he feared from the social scandal (Karki 56). Her younger brother, who loves her and who has given her shelter, also fears that the society may boycott them in case he dines with her, who is not a high caste Brahmin now. So, he instructs his wife that she should not be placed in his hierarchy while having rice. He reminds her: "tã kina abujha banchhes? didīlaì bhānchhāmā misauna mildaina. [Why do not you understand? Now we cannot assimilate elder sister in the kitchen]" (61). His brother is a victim of superstitions; as a prisoner of dogmatic belief he fears the society. But, Yogamaya fears no one, and she starts her rebellion by discarding her caste and accepting food from the untouchable.

Now, Yogamaya decides to protest and rebel every type of injustice in the society. She wants to uproot traditions and customs based on superstitions. From a helpless victim she transforms herself as a social reformer, a rebel. She walks around the village, goes to the functions like the Purān and argues and denounces the priests for promoting injustices. Her first and foremost target is the priests. She believes because of them women and untouchables suffer. She argues that one cannot be a Brahmin by birth, but one can be because of his knowledge and good deeds:

brahma chinne brāhmaṇ bhanī uttar garāe, brāhmaṇharūle satya chhāddā deva darāe.

[They reply that one who knows the truth is Brahmin, the god fears the falsehood of Brahmins.] (109)

Her denouncement of Brahmins' superiority infuriates her brother Agnidhar. So, he warns her not to meddle in their profession. But, she casts off her femininity by breaking up the muffled voice and resists:

ho bhaneko hu. bhanchhu. pheri pani bhanchhu. ekapataka hoina. bhana pare sayaũ pataka bhanchhu. bhanna pani parchha." [Yes! I have said. I will say. I will say it again and again. I will say in hundred times, and it needs to be said.] (108)

Now as a bold and rebellious woman, she insists that she will speak against the injustices.

Here, lies an affinity between her proclamation and Cixous' suggestion to women to break up the silence through their writing. Cixous suggests that "women should break out of the snare of silence. They shouldn't be conned into accepting a domain which is the margin on the harem" (888). Similarly, Yogamaya, fearlessly, explains that Brahmins have been responsible for the pervasiveness of superstitions; and they have misled people in the name of religion (Karki 110). She uses her logic and argument to fight against the injustices.

She uses unique ways to attack injustices and campaigns to raise people's awareness. She employs religious practices to combat the injustices promoted in the name of religion. Her activities align with Shoma A Chatterji's suggestion. Chatterji suggests, "Since patriarchy is all 
- pervasive, it cannot be attacked from any neutral positions. The only position left is to combat patriarchy from within" (44). Likewise, Yogamaya sits for meditation, composes lucid and simple verses; and she recites them eloquently after coming out from her meditation during the prayers. In this way, she manipulates the religion, the notion of redemption and motivates her people to seek redemption here on earth.

However, Yogamay's verses are not necessarily devoted in the praise of gods and goddess; they are revolutionary in their spirit. Her verses subvert religion by exposing the inherent patriarchal biasness in it. The listeners find the logic of her verses irresistible, and they join her. Gangadevi, the narrator narrates her strategy: "did̄̄le kati kurā churo samātera ślokamai bhannuhunthiyo. [Sister would deliver many ideas in verse catching the crux of the matter]" (110). Her verses are subversive, politically charged and hit at the crux of the matter. She fears none. The narrator adds:

did̄̄ dagne darāunemā hunu hunnathiyo; hākāhākī bhanidinuhunthiyo, 'ho ma poila gaekī hũ. ma bigriekī hũ. lognemānchhele swāsnī hüdāhüdai dosro, tesro najāne kati swāsnīko māla lāuna hune? swāsnī māchhele bādhyatyāmā sãghar nāghana nahune? [Elder sister would not be feared and frighten. She would confess straightly, 'yes! I have eloped. I am a spoiled one. Men can bring second wife, third wife, who knows how many? Cannot a woman cross the threshold in compulsion?] (110)

She boldly confesses her deviation and insists that she had not option. She argues for gender equality and questions the validity of patriarchal double standards in terms of morality.

Moreover, she rebels against caste system by renouncing her caste. She is a Brahmin woman, but she becomes the victim of Brahmin's exploitative marriage system that forces girls to marry in early age and continue staying with the in-laws despite the ill treatment. Besides it bans remarriage. She realizes that without breaking the caste hierarchy women's freedom is impossible. Hence, she campaigns against the practice of child marriage and against the ban of remarriage. She accepts food and drinks form the low caste people who have been treated as untouchables. She justifies that the essence of water to quench one's thirst has not been changed; nor has it become impure by the touch of the so called untouchable (148). She analyzes the belief systems objectively, and exposes the exploitative and irrelevant practices of those systems.

In this way, she rebels against gender, caste and class discriminations. She makes people realize that discriminations are created by men and can be changed. She makes them aware of the fact that there is no gender specific work. Through her own activities, she proves that masculinity is not limited to men as she sits for deep meditation nights and days, spends longer periods of isolation in caves and wanders alone through the jungle. These are the activities 
unheard of women. When one of her supporters evaluates her activities in terms of her gender, she reminds:

malā̄ mātra hoina sabai mānchhelā̄ pahilā linga nachhutā̄ mānchhekai rupamā hernu. pheri pani jājtamai aḍkiyã hoina hāmī? . . . bhinnatā jyũ kā tyũ. [Including me, all should be first treated as human being not as a gendered being. Have we again fixed in caste ... ? Discrimination is intact.] (314)

It shows her transformation of the feminine self. She wants both gender and caste equity. Thus, she welcomes all in her hermitage: "yahãāunu sabailāì chhuța chha. jātabhāta uchanīcha, dhanī-gariba, janānā, mardānā kohhīmà bandeja chhina. [All people can come here. Here is no caste, gender or class bars]" (346). She believes that oppression of women is not based upon their biology, but it is social and, therefore, changeable. Like Cixous she rejects the notion that "anatomy is destiny" ("Sorties" 155). She acts as par her belief; renounces her caste, becomes an ascetic, a sanyasī, who is free of the bondage of cast. In addition, she discards family life and lives in a commune by establishing äshrams, where men and women of all castes and classes are treated equally. As a rebel she acts for radical change.

Indeed, Yogamaya is a rebel and acts for radical change. She seeks to alleviate the social plight in which women, poor people and low caste people find themselves. Her activism matches Cixous' dictum. Cixous claims that sexual transformation cannot be achieved without political transformation, which is radical ("Sorties" 115). Yogamaya aims for the radical change of the society. Verses and songs are her main medium to expose the prevailing injustices in the nation. For instances, she attacks the corrupt bureaucrats through these lines:

ahile garchhau bhaladmīho āphnā khuśaile

bhitrī jarā hālisakyo lobhī ghusaile.

[Now gentlemen you enjoy taking bribe/ the corruption has settled permanently.] (309)

Her verses provoke people to fight against dictatorship, corruption and abuses. Highlighting the political mission of Yogamaya's verses, Barbara Nimri Aziz writes: "Yogamaya composed and uttered verses when she came out of her meditations. They aroused thousands to come together and call for radical political change" (xxxvi). Nimri Aziz adds that her verses "embody the very principle of equality and the anti- Brahaminic messages central to Yogamaya's teaching" (34). True to Nimri Aziz's evaluation, the verses of Yogamaya are full of political messages, which inspire, unite and mobilize her supporters to fight against the injustices.

Yogamaya strategies can be interpreted in feminist terms. Cixous suggests that women should challenge the patriarchal models of thought based on binary opposition. For this they should write poetry. She argues for breaking the genres - integrating philosophy and poetry 
women can be subversive. Cixous insists, "A feminine text cannot fail to be more than subversive" ("Medusa" 888). Gangadevi, one of the narrators, narrates Yogamaya's story to her daughter Dukhuna and makes her compose her story. The narrator, the poet Yogamaya within the narration, breaks the genre. The purpose of the hajurabāni, verses composed by Yogamaya, is to make people aware of the prevailing injustices in the nation. They are hermits, religious devotees. They sing the songs in the praise of the Lord; so they call her Bhakti hajura. But, at the same time, they recite the verses which are politically charged, reasoned and argumentative, but sound lucid and rhythmic.

Gangadevi's campaign in the fiction level and the novelist's act in the real life level align with Cixous. In "The Laugh of the Medusa," she urges that women must write and they should write about women. She calls out to women saying: "Now is the time to write!" She believes that through the written words women can redefine themselves be their own preferences and subvert the repressive hierarchy created by patriarchy (876-77). Reasonably, for social and cultural transformation, women must write. Likewise, Yogamaya's verses, too, are capable of changing people's mind-set.

Yogamaya is a true rebel working for the larger purposes. She wants to bring radical change throughout the nation. Although her supporters are increasing and protesting against every type of injustice in the local level, they are unable to uproot superstitions, gender, caste and class discriminations, corruption of the bureaucracy and the merchants. Yogamaya believes that breaking the evil practices in the local level, they cannot emancipate the nation. Unless and until the government outlaws such practices people continue to suffer. She explains:

hāmīle yī-yastā kurā aba yahã mātra garì basera bhaena. aba sidhai māthi purāunuparchha. yo simle, kulun, dinlā, majhuwābẽ̃̄i hāmrā gāügharkā mātra nabhayera purai rājyakai samasyā ho. rājyalenai yasabāta muktti pāunuparchha.

[We should not limit our activities at the local level, it should be taken to the government. These problems are not limited to Simle, Kulung, Dingla, Majhuwabesi or to the periphery of our village. Rather these are national issues. The nation should be emancipated from such problems.] (244)

She wants justice for everyone. For this, the government should illegalize every type of discrimination.

Furthermore, Yogamaya believes that the ruler of the nation has power to draft and implement rules for social reformation. Therefore, she dispatches petition to the Prime Minister of the nation. When things do not work, she herself, along with her supporters, goes to Kathmandu and submits her petition to the government for implementing rules that will ban all sorts of discriminations; will ban child marriage and allow widows remarriage. After the 
government assurance, they return to Majhuwabesi, where Yogamaya continues her rebellious activities.

Yogamaya's indomitable spirit is ready to brave and defy any exploitative tradition and fight any individual or institution. She thinks it is no use requesting the government through the petition. She convinces her supporters that, as freedom fighters, they should be ready to sacrifice themselves for the sake of freedom. She decides for self-immolation by fire to pressurize the government to reform the rules. Her supporters also join in her decision. She dispatches an ultimatum to the Prime Minister, Juddha Shamasher Rana stating that if the government does not address their demands, they will collectively suicide jumping in the fire; and the government will be responsible for the mass suicide. She states in her ultimatum: "yah̄ kartik sukla purnimāko dinasamma āphnā prtigyā pūra nagaremā hamī prāna tyāga garne chham. [Unless the government meets its commitment by the full moon of the month of Kartik, we are going to immolate ourselves]" (392). As a real rebel, she has overcome the fear of death and dispatches the ultimatum to the Prime Minister. She, along with her supporters, continues chanting slogans, warning the government to address their demands. She composes more verses. Her followers make copies of her politically charged verses and circulate them among the people.

She is a rebel; therefore, the government fears the consequences of their action and arrests the protesters. The freedom fighters are taken to the custody and the government agents confiscate their documents. She is invincible, as she reminds the troops that justice cannot be delayed forever (402). Despite the harassment and suffering, she continues her awareness raising program in the prison as well. Later, she realizes that they may perish in the jail and their dream will never be materialized. The government offers amnesty on the condition that they will not suicide and will not recite hajurābanī, which she accepts.

The government releases her after she agrees to discontinue her activities. But, after they are released from the jail, she again unites her supporters at her āśramas and starts rebelling against the government cautiously. She reaches to the conviction that it is not enough to change the society from the individual level. For the revolutionary changes, the government should make the decisive rules and strictly implement them. But the government's apathy toward the prevailing injustices and corruptions and the rulers sheer disregard to address the rebel's demands make her more rebellious and aggressive. The rulers seem to be blindfolded. To open their eyes and revolutionize the whole country, she decides to jump in the flooded Arun River with her supporters. Thus, she along with her sixty seven followers perishes into the river one by one claiming that injustices will fly away and justice will rule the nation. Another narrator, Dukhuna, writes: 
paisațthī janakà pāilāharū agādi baḍhadai chhan. gadgaḍairaheko arunatarpha hiḍdai chha-ujyāloko laskara. eutai chha āwāja adharmako nāsa hos. dharma rājya sthāpanā hos.

[The line of sixty-five people is moving ahead - Towards the flooded Arun - the line of light with the single voice -

let the corrupt rule end/ let the good governance begin. (481)

In this way, from the status of a victim, she emerges as a freedom fighter, a rebel, who in the pursuit of justice, sacrifices herself.

\section{Conclusion}

Based on the real life story of Yogamaya, a sage cum social reformer, the novel chronicles her journey from subjugation to rebellion. Her own personal sufferings as a woman, masculine biasness of her father, and the bias religious and cultural practices of Hinduism that restrict women's mobility, spark the flame of rebel in her. In addition to these factors, the prevailing caste and class discriminations of the society, corruption of the bureaucrats and the government's sheer apathy to redress the injustices and corruptions make her a rebel. She subverts patriarchy within its bound. Initially, she covertly rebels the system by breaking the bans on women's remarriage and widows' remarriage. But, later she rebels aggressively mobilizing the mass. She uses unique strategies: acts as an ascetic: sits for meditations, composes verses and recites the verses, which are revolutionary in nature, during the prayers. People are mesmerized by the logic and argument of her verses; they find her irresistible and join in her campaign. Finally, she emerges as a freedom fighter, a rebel, who plunges in the Arun River along with her supporters to pressurize the government. In this way, from the status of a silent victim, she transforms herself into a ferocious rebel feared by the nation. The way, the novelist, traces her journey from a victim to a rebel suggests what a female is capable of doing. However, this article deals only with the transformation of the feminine self of Yogamaya in the novel, future researchers can analyze the text from gender and Marxist perspectives as well.

\section{Works Cited}

Atreya, Tika. "Pustaka Samikshyā: 'Yogamāyā' Eka Nyāyika Phaisalā." [Book Review: Yogamāyā, a Just Verdict."] http://janasawal.com/index.php/detail/2018-05-3319884066

Beauvoir, de Simone. The Second Sex. Translated and edited by H. M. Parshley, David Campbell, 1993.

Bhaukaji, Bimal. "Yogamāyāko Āyāma." [The Dimension of Yogamāyā.]

https://nagariknews.nagariknetwork.com/news/47736/ 
62 JODEM: Journal of Language and Literature, vol. 10, no. 1, issue 12, 2019/2076BS

Chatterji, Shoma A. Women in Perspective: Essays on Gender Issues. Vitasta, 2010.

Cixous, Helene. "The Laugh of the Medusa." Signs, translated by Keith Cohen and Paula Cohen, vol. 1, no. 4, Summer, 1976, pp. 875-893. JSTOR, stable/3173239

---. "Sorties: Out and Out: Attacks/ Ways Out/Forays." The Logic of the Gift: Toward an Ethic of Generosity, edited by Alan D. Schrift, Routledge, 1997, pp. 148-73.

Karki Niharika, Neelam. Chìraharana. [Robbing of the Clothes]. Sangrila Books, 2073 BS.

---. Yogamāyā. Sangrila Books, 2074 BS.

Nabar, Vrinda. Caste as Woman. Penguin Books, 1995.

Nimri Aziz, Barbara. "Mānaba Śāstra Bhandā Māthi." ["Higher than Anthropology."] https://www.kantipurdaily.com/koseli/2018/10/06/1538794272132442

Okin, Susan Moller. "Feminism, Women's Human Rights and Cultural Differences." Decentering the Center: Philosophy for a Multicultural Post-Colonial and Feminist World, edited by Uma Narayan and Sancha Harding, Indiana UP, 2000, pp. 26-46.

Poudel, Anjana. "Yogamāyā: Eka Saṅgharṣaśhila Samāja Rupāntaraṇa Kartā, Abhiyantā." ["Yogamaya: A Social Reformer and Activist."] http://www.khasokhas.com./52081

Timalsina, Ramji. "Itihāsamāthi Jīwanta Sambodhana." ["Lively Address to History."] Phursad, Annapurna Post, March 10, 2018, p. chha.

Tong, Rosemarie. Feminist Thought: A More Comprehensive Introduction. 3rd ed., Westview Press, 2009.

Tyson, Lois. Critical Theory Today: A User Guide. 2nd ed., Routledge, 2006.

"Yogamāyā Liera Nīlama." ["Neelam Brought Yogamāyā."] Kantipur, February 19, 2018, p. 14. 